\title{
HYDROPOLITICAL COMPLEXES AND ASYMMETRICAL POWER: CONFLICT, COOPERATION, AND GOVERNANCE OF INTERNATIONAL RIVER SYSTEMS
}

\author{
Jenny R. Kehl, Ph.D. \\ Department of Political Science \\ Rutgers University-Camden \\ jrkehl@camden.rutgers.edu
}

\begin{abstract}
Hydropolitical complexes are emerging to negotiate water-sharing policies that promote political stability, regional security, economic prosperity, and environmental sustainability. Yet interstate disputes are occurring within most hydropolitical complexes, and weak riparians are often coerced to agree to water-sharing policies that adversely affect them. This research examines the strategies weak riparians use to assert leverage in international river basins with asymmetrical power, and the success of those strategies in achieving cooperation versus conflict. Grounded in the theoretical framework of hydro hegemony, hard power, and soft power, this study uses cross national analysis to test the effects of geographic, military, political, economic, technological, and external influence on water governance in eight international river systems. The results demonstrate that weak riparians mobilize the assets and capacities of external actors, such as donor countries and the World Bank, to increase their leverage within hydropolitical complexes. The study finds that strategies to balance hard power are largely ineffective; they fail to achieve cooperative water-sharing arrangements and often exacerbate conflict. In contrast, strategies to balance economic power and soft power, such as market access and political legitimacy, are more successful in promoting cooperation and preventing conflict in hydropolitical complexes.
\end{abstract}

\section{INTRODUCTION}

Hydropolitical complexes are emerging to negotiate water-sharing policies that promote political stability, regional security, economic prosperity, and environmental sustainability. Yet international water disputes are occurring within most hydropolitical complexes. The decision to resolve these disputes through negotiated settlements or to escalate the disputes into violence is a complicated and contentious calculation. Water-based explanations of conflict and cooperation need to incorporate economy, ecology, technology, security, politics and policy. As Arun Elhance articulates in his seminal work Hydropolitics in the Third World: Conflict and Cooperation in International River Basins, the multiple-use of transboundary water makes hydropolitics "one of the most urgent, complex, and contentious issues that the developing countries and the international community will have to face and resolve in the next century" (1999:4). Although there are successful water-sharing arrangements, the cooperative management of international water basins is still extremely rare (Elhance 2000). One substantive impediment to cooperative management is power asymmetry in hydropolitical complexes, which affects the legitimacy, complexity, and feasibility of international water-sharing arrangements. 
The purpose of this research is to examine the dynamics of hydropolitical complexes international organizations of states that share a river system- and the strategies weak riparians use to promote cooperation in international river systems with asymmetrical power. Riparians have a land bank adjacent to a natural watercourse or body of water, and they have a right to reasonable use of the water, albeit undefined. International river systems have multiple riparians, which are sovereign but interdependent.

Strong riparians with a disproportionately high amount of political, economic, and military leverage can often coerce weaker riparians to agree to water-sharing policies that adversely affect them. Weak riparians do not have sufficient resources to balance asymmetrical power, so they frequently appeal to international actors outside the hydropolitical complex. The cross sectional analysis in this research provides empirical evidence to support the importance of external international influence on asymmetrical power relations, negotiations, and cooperation within hydropolitical complexes. The research also offers additional insights to support previous work that has illustrated the complexity and necessity, in many cases, of international involvement in river system management. Three important examples stand out: first, the research of Ariel Dinar and Senai Alemu on the impasse in the negotiations over the Nile watersharing policies in 1997, which resulted in the Nile riparians requesting the involvement of the World Bank to provide financial incentives to promote cooperation (Dinar and Alemu 2000). Second, Greg Browder's research on the Mekong Agreement emphasizes the role of donor assistance to overcome the mistrust that had tainted negotiations in the past (Browder 2000). Finally, Elhance and Dinar's critical works on hydropolitics conclude, "during the long and often frustrating process of negotiating water-sharing agreements many formidable obstacles have to be overcome. Sustained support by third parties is often critical in creating and maintaining the momentum for such negotiations" (Dinar 2000:220; Elhance 2000). In the interest of understanding the role of third parties and the strategies of weak riparians to promote cooperation in international river systems with asymmetrical power, the guiding questions of this analysis are: How do weak states encourage strong states to establish equitable water-sharing agreements? How do weak states gain leverage in negotiations? How do weak states re-negotiate watersharing policies that adversely affect them in the long-run? To what degree do weak riparians turn to external forces, resources, and allies to balance power within the hydropolitical complex?

The theoretical framework of hard and soft power (Nye 2004) holds considerable explanatory value for addressing these questions, particularly regarding the hard power of geographical riparian location, military capacity, and the "sticky power" (Mead 2004) of economic influence. Hydropolitical complexes differ from traditional security complexes in several ways. The most important distinction is that traditional security complexes are organized to balance the power of external actors or adversarial security alliances, while hydropolitical complexes are organized to address conflict between the riparians within the hydrological basin or international river system. In the Nile river system, for example, Egypt has the greatest military capacity, economic dominance, and political power in comparison to other riparians such as Ethiopia, Sudan, Rwanda, and Tanzania. This power translates into a disproportionately high amount of water use for Egypt, even though Egypt does not control the headwaters of the Nile and depends on the deference of other riparians (Klare 2001). The weaker riparians can leverage their geographic advantage of controlling the headwaters of the Nile but this provokes volatile conflict with Egypt, which threatens to use military force if necessary to protect its disproportionately high access to the water from the Nile. To avoid conflict with Egypt, the 
weaker riparians are coerced by Egypt's hard power to agree to inequitable water-sharing policies that may adversely affect them in the long run.

To complete the story, however, the Nile Basin Initiative demonstrates that the hydro hegemonic power (Zeitoun and Warner 2006) of Egypt is not total, and cooperative frameworks for water-sharing continue to develop. The hard power of geographic riparian location, in addition to the external influence of the World Bank and United Nations Development Programme, have left room for the otherwise weak riparians to negotiate water-sharing arrangements. The Nile Basin Initiative has achieved a remarkable amount of credible commitment and cooperation, "given Egypt's regional dominance and historical disregard for other riparian states" (Posthumus 2000), but faces substantial obstacles to the sustainability of the agreements. Most of these obstacles are related to hard and soft power asymmetry within the hydropolitical complex: specifically, the ongoing conflict of interests between upstream and downstream riparians, the lack of legal codification and institutionalization, economic inequality, trade dependence, and persistent armed conflicts between the riparians and throughout the region.

This research augments regional insights and anecdotal evidence from pervious work by developing a database and conducting a systematic empirical analysis of power dynamics within several hydropolitical complexes. Cross-sectional regression analysis is used to test the effects of geographic, military, political, economic, and external factors on water conflict resolution in eight major international river systems. The results expose the asymmetrical power dynamics within hydropolitical complexes, and suggest internal and international adjustments to make weaker riparians less easily exploitable in water-sharing policies. In sum, this analysis specifies the political, economic, and international conditions in which weak riparians and dominant riparians assert distinct types of power, and the success or failure of those strategies to promote cooperation versus conflict.

\section{ANALYTICAL FRAMEWORK}

One of the difficulties in analyzing cooperation in international river systems is that the same factors, such as water scarcity or economic development, can trigger conflict or cooperation. Hydropolitical complexes are evolving as transnational institutions to facilitate cooperation by providing incentives and imposing constraints, as well as disseminating information about the costs and benefits of cooperation versus conflict. It is generally accepted that transnational institutions have boundaries, structures, rules, coherence, and agency (Wallerstein 1974), but it is often forgotten that the refinement of the transnational institutional framework was influenced by research on geo-ecological regions that cross state boundaries (Braudel 1979). This legitimation of geo-ecological regions as units of analysis is important for the study of water basins that cross political boundaries. Hydropolitical complexes negotiate policies and treaties for geo-ecological regions identified by a shared international water resource. Transnational complexes can increase the benefits of cooperation and increase the costs of conflict for member states. However, relative inequality and power asymmetry within hydropolitical complexes can distort the distribution of costs and benefits, and can be used to compel weak states to agree to water-sharing policies that adversely affect them in the long term. This study examines the internal power asymmetries and power dynamics of hydropolitical complexes, as well as the ongoing dependence of the weakest riparians on external actors and the foreign interference effect. 


\section{JOURNAL OF WORLD-SYSTEMS RESEARCH}

Relative inequality and power asymmetry between the member states in a hydropolitical complex can distort the costs and benefits of conflict versus cooperation. An influential study by Bertram Spector concludes that one of the crucial variables in facilitating conflict or cooperation is the relative inequality between parties (Spector 2000). The inequalities in hydropolitical basins are long-standing. The most fundamental inequality stems from nature's unequal distribution of natural resources. Natural geographic and environmental inequalities have been exacerbated by population growth in developing countries and unprecedented levels of human consumption in wealthy and newly industrializing countries. Historical and structural inequalities such as the legacy of colonization, primary commodity dependence, and global trade practices perpetuate core-periphery inequalities. In the context of this global system, hydropolitical complexes function as "mini world systems" (Wallerstein 1974) in which weak states have structural disadvantages that cause them to develop in a way that reproduces their subordinate status (Chase-Dunn and Grimes 1995). Structural, political, economic, and environmental inequalities are exacerbated by power asymmetry in hydropolitical complexes, and affect the type of leverage riparian states use to negotiate water-sharing arrangements.

In hydropolitical complexes with relative inequality and asymmetrical power, leverage is asserted through the geographical location of riparians, financial resources, commerce, access to information, technology transfer, military capacity and mobilization, and other sources of power that vary widely between riparians. A parsimonious framework for understanding these dynamics is the asymmetry of four types of hard and soft power: structural power, sticky power, political power, and ideational power. Hard power includes military might, geographic location, and hydro hegemony (Zeitoun and Warner 2006), in which the hydro hegemon, such as Egypt on the Nile, asserts structural power over other riparians in the hydrological basin. The indicators of hard and structural power for this analysis are domestic military capacity, international military support, military mobilization, hydro hegemony, and geographic riparian position at or near the headwaters of the river system. The substantive discussion of these factors is narrowed for the statistical analysis, which uses the variable of military mobilization to indicate leveraging of hard power and the variable of proximity to the headwaters to determine the level of control over the headwaters. Sticky power (Mead 2004) is economic power. It is the capacity to leverage trade and aid over other riparians that may be economically dependent. For this analysis, sticky power and economic dependence are measured as economic capacity (GDP), amount of trade plus aid from other riparians, amount of trade plus aid from external actors, international financial aid as percent of GDP, and level of market access. For the statistical analysis, the leveraging of economic power is measured as the amount of bilateral trade plus aid from another riparian in the hydropolitical complex. Trade plus aid from an external source (external to the hydropolitical complex) is considered in the section on external influence on hydropolitical conflict and cooperation. Soft power, as articulated by Joseph Nye, comes in the form of political power and diffusion of ideas (2004). Political power is the capacity to control political decisions and secure compliance. This capacity is indicated by political legitimacy, pre-existing legal agreements, and political leverage. Political legitimacy in the form of democratic accountability is considered to be one of the strongest predictors of the sustainability of water-sharing policies (Elhance 2000), and is used as a regressor for the statistical analysis. Ideational power is generally defined as the diffusion of ideas, technology, culture, and values (Lukes 1997). It is difficult and subjective to quantify the variables of ideational power. Therefore, this study uses the variable technology 
transfer, which is quantifiable and reliable, to indicate ideational soft power. The variable specification is discussed in the Methodology and Elements of Analysis section.

The internal power asymmetries in hydropolitical complexes hold substantial explanatory value for understanding cooperation and conflict in international river basins, and for identifying the reasons weak riparians often comply with disadvantageous policies. Yet internal power dynamics alone do not capture the consequential relationship between hydropolitical complexes and the global system. The analytical framework would be incomplete and the model would be misspecified if it did not consider the foreign interference effect. Weak states may not have the resources or power to offer incentives for cooperation and impose constraints on stronger riparians, however, they frequently turn to foreign states to provide the necessary incentives and constraints. Foreign states play a crucial role in levying resources and leveraging power in international water systems, and this role may become increasingly important as water resources become increasingly scarce and international water-sharing practices become increasingly contentious. As articulated by Arun Elhance, "sustained international initiatives and support are often needed to overcome the many barriers to interstate cooperation in hydropolitics and to persuade and enable the respective riparian states to see cooperation as a "win-win" situation for all concerned" (1999:7). Strong riparians have the power to compel weak riparians to comply with water-sharing arrangements that may adversely affect them, but if the weak riparians gain the support of external actors to provide incentives and impose constraints, the strong states may not be able to "win" unless they participate in a cooperative negotiation process and a more equitable water-sharing policy.

The Nile Basin hydropolitical complex illustrates the link between theory and practice, and exhibits all the major elements of the analytical framework: the internal power dynamics of the hydropolitical complex as well as the dependence of weaker states on appeals to external sources of power. The strongest riparians control the headwaters or upriver points of contention, have superior military capacity, can assert political pressure over weak riparians, have strong economies that other riparians may be dependent upon for trade or aid, or have access to advanced water-extraction and water-use technologies. Hydro hegemons and other strong riparians have several overlapping advantages. For example, Egypt has clear economic, political, and military dominance over weaker Nile riparians, even though Egypt does not control the headwaters. Egypt uses that leverage to control decisions about water-sharing, and to coerce weak riparians to agree to polices that may adversely affect them in the long run. Past leadership in Egypt has successfully asserted its military power by threatening that Egypt will go to war, if necessary, over water. The weaker riparians, however, have appealed to the external influence of the World Bank to provide exogenous incentives for Egypt to cooperate. The World Bank finances most of the world's major hydroelectric projects, but refuses to fund projects that do not have the full cooperation and compliance of all riparians in the international river system. Therefore, Egypt will not receive World Bank funds for its water projects in Egypt or elsewhere on the Nile unless all riparians give their consent for the project. It is important to recognize that this power dynamic can be utilized by both weak and strong riparians, depending on the preferences of the World Bank or other external forces. This dynamic alone merits an independent study, but for this analysis it illustrates one of the ways weak riparians may be able to identify less traditional sources of leverage or appeal to external forces to compensate for their lack of capacity and resources to influence water-sharing arrangements. 


\section{METHODOLGY AND ELEMENTS OF ANALYSIS}

Cross Sectional Time Series regression is used to test statistical correlations in this analysis because it can illustrate spatial relations and temporal dynamics of the strategies that promote cooperation versus conflict. It identifies distinct patterns in the use of geographic, military, political, economic, technological, and external-appeals strategies by the weak riparians and strong riparians, and the outcomes of those strategies in achieving cooperation and preventing conflict. The analysis also tests the effects of contributing factors such as ethnic conflict, economic inequality, and the level of dependence on the shared water source. The data consist of 52 country-cases in eight major international river basins from 1950-2007: the Nile, Zambezi, Parana-La Plata, Amazon, Jordan, Ganges-Brahmaputra, Indus, and Tigris-Euphrates basins. If cooperation is achieved and a water-sharing agreement is established in an international river system, the study assesses the sustainability of the negotiated settlement by testing a lag to verify if the agreement was maintained or broken within a year.

The cross-sectional analysis addresses four basic statistical considerations common to CSTS in the interest of correctly establishing correlation: time order, heteroskedasticity, autocorrelation, and spuriousness. Time order is assumed for this study. The data are structured in time-series panels, chronologically by year, so the assumption of time order is not problematic. However, time-series analysis can produce heteroskedasticity, which results in biased and inconsistent results. This study uses panel-corrected standard errors to correct for heteroskedasticity in the error term and to provide better coefficient estimates. Another common problem in CSTS regression is autocorrelation, the correlation of the variables beyond the boundaries of the dataset and the time constraints. Panel-corrected standard errors are used to make minor statistical corrections, although autocorrelation is not shown to be highly problematic in this particular study. Cross-section analysis can also suffer form spuriousness, which exposes the possibility that the statistical relationship is caused or distorted by variables not specified in the model. Non-spuriousness is achieved by controlling for the three most plausible sources of spuriousness in the analysis of hydropolitical complexes: economic inequality, ethnic conflict, and the level of dependence on the shared river.

The 52 country-cases are standard and designated by the official United Nations' definitions of the countries and territories in each international river basin (See Appendix I for country-cases listed by river basin). It is important to note that the country-case total includes large country-cases such as India and China that are riparians in two different hydrological basins. For example, India is a country-case in the Indus hydrological basin and the GangesBrahmaputra hydrological basin, and India is a member-state of each hydropolitical complex. The distinct cases are referred to as India-Indus and India-Ganges.

The international river systems are selected based on wide variation in the power distribution within the hydropolitical complex and the types of strategies used to assert influence, which translates into maximum variation in the independent variables for the statistical analysis. The second essential consideration in the case selection is the availability of data that are double documented. The eight international basins selected for this analysis have data that can be measured and documented, whereas other basins require additional data collection in the field before the variables can be quantified and verified. Substantive examples from the Nile Basin are used to illustrate the central points of this quantitative analysis, which will be followed by a 
qualitative comparative case study of hard and soft power dynamics in the eight hydropolitical complexes, a seven-year field work study nearing completion in 2009.

\section{Dependent Variable}

Conflict and Cooperation. The dependent variable, cooperation versus conflict, is specified on a spectrum developed by the North Atlantic Trade Organization (NATO): 1) negotiated settlement, 2) qualified negotiated settlement, 3) unresolved dispute, and 4) violent conflict (NATO 1999). At the turn of the century, NATO re-articulated its definition of security alliances with a stronger emphasis on the relationship between energy security, resources security, and economic security. Applied to international water management, NATO describes a negotiated settlement as the result of cooperation to achieve a water-sharing policy or to resolve a water dispute. A qualified negotiated settlement is cooperation that is preceded by any form of military action or perceived threat. An unresolved dispute is the failure to achieve a negotiated settlement, and violent conflict is the failure to avoid the use of violence in addition to the failure to achieve a negotiated settlement (NATO 1999). Hydropolitical complexes are not always in a state of negotiating settlements or experiencing conflict, and the absence of conflict does not necessarily indicate the presence of cooperation. Thus, for the purpose of this study, the dependent variable measures a change in the status quo of conflict or cooperation, or lack of either. The NATO designation of the dependent variables is widely accepted and internationally recognized as a measure of cooperation and conflict; and, despite its limitations, holds considerable explanatory value for understanding the levels of conflict and cooperation in hydropolitical complexes.

\section{Independent Variables}

The independent variables represent conceptual categories of power. The variables are indicators of military, geographic, economic, political, technological, and third-party sources of leverage. The conceptual category of hard power, or structural power, includes military and geographic variables.

Military mobilization. The leveraging of military power is indicated by the change in the level of military mobilization at the border of other riparian countries. The level of military mobilization is measured as troops levels and documented by the Correlates of War project. The variable is calculated as the change in the level military mobilization. Change is measured and standardized on an interval scale, meaning the difference between the levels of an attribute that are positive (affine) and linear, which is appropriate for regression analysis.

Control of headwaters. Geographic location is the most intuitive type of leverage in hydropolitical complexes, and the most static: measured as proximity in kilometers to the headwaters. The countries that control the headwaters or the points of contention can assert leverage by threatening to alter the water supply to countries down river. Although the proximity (distance in kilometers) to the headwaters can be found in many data sources, this study uses UNWater data, managed through UNESCO, because it is consistent and uses the geographic identification of the water source, rather than localized or politicized identifications of the water source.

Economic power is a conceptual category, often referred to as sticky power, which encompasses production, consumption, market size, market access, trade and aid rules and 
practices. Most of these variables co-vary, which generates statistical problems, so this study selects the type of economic power that is leveraged most often in negotiations over watersharing agreements: trade and aid.

Trade and aid. Trade and aid can be easily leveraged. Riparians can promise to increase trade and aid as an incentive to promote cooperation, and they can threaten to reduce trade and aid to enforce cooperation. It is important to note that economic leverage can also be used to compel dependent riparians to agree to water-sharing policies that adversely affect them in the longrun, for fear of loosing trade and aid from wealthier riparians. The variable trade and aid is measured as the bilateral trade plus aid between diads of riparians, as a percent of GDP. The total amount of trade plus aid is important in transnational negotiations, and the percent of GDP can infer a level of dependence on trade and aid, which might affect the outcome of asserting economic power.

The conceptual category of soft power refers to political power and ideational power. Soft power is asserted to compel agreement and enforce compliance, and often takes the form of legitimation and diffusion.

Political accountability. Political power is the capacity to offer political gains or threaten political condemnation, which affects economic relations, diplomatic relations, military relations, and inclusion in the decision-making structure of the hydropolitical complex. The efficacy of offering political gains or levying political threats is largely determined by the credibility of the regime that leverages the gains and losses. Illegitimate regimes do not have the political credibility or accountability to assert political power, especially at the international level, although they often compensate by using other forms of power such as structural, economic, or military power. Political credibility, in the form of political accountability, is also salient for hydropolitical complexes because accountability is a strong indicator of the willingness of states to enter into water-sharing agreements with other states. Political accountability increases trust and decreases risk for riparian states. It has been stated that "...democratic polities are also often the best guarantors of the acceptability and longevity of international water accords" (Elhance 2000:215), but this variable posits that it is the broader concept of political accountability, which may or may not manifest as democratic polities, that increases credibility and political power.

Technology transfer. Another source of soft power that can be leveraged is ideational power: access to and diffusion of information and advanced technologies. Accurate information, reliable data, energy, infrastructure, and access to technologies that improve water-use efficiency in industry or agriculture are highly valuable in water-scarce regions. Access to information and technology can be transferred or withheld in order to affect the outcome of negotiations over water-sharing policies. Technology transfer has only recently been quantified and recorded as data, and is not available for most of the fifty-seven year time-span of this study. Thus, technology transfer is measured as a change in the level of technological capacity, documented by the World Bank, which can be indicative of diffusion.

External power. If riparians do not have the resources or domestic capacity to assert leverage in negotiating water agreements, they can appeal to external international actors for support. Hydropolitical complexes are intended to offer incentives to cooperate and impose constraints on conflict over shared water. However, weak riparians often do not have the resources or power to offer incentives and levy constraints, and may appeal to external international actors to do so. Foreign governments, non-governmental organizations, and international financial institutions may assert economic, political, or military leverage on the 
member-states of hydropolitical complexes, if it is in their interests to promote cooperation versus conflict. Although external power has many dimensions, magnitudes, and measures, this study uses the change in total trade plus aid from external sources (external to the hydropoltical complex) to indicate the foreign interference effect.

Additional contributing factors include economic inequality, ethnic conflict, and the level of dependence on the shared-water source (what percentage of a country's water comes from that water source alone).

Economic inequality. The level of economic inequality between the riparians within a hydropolitical complex affects the utility of different types of leverage. For example, if there is a high level of economic inequality, measured as the disparity in GDP per capita between states, economic leverage such as trade and aid might be more effective.

Ethnic conflict. Ethnic conflict may disrupt or distort the negotiation process of establishing water-sharing agreements. Ethnic conflict also destroys infrastructure, absorbs resources, and generates opportunity costs that affect the possibilities for cooperation in watersharing policies. Ethnic conflict is measured as the events of ethnic conflicts that report human injuries, as documented by the Correlates of War database.

Dependence on the shared river. The level of dependence on the shared river also affects conflict and cooperation. Some riparians may be more dependent on one water source, whereas other riparians may have access to alternative water resources. For example, Egypt is almost entirely dependent on the Nile for its water. Therefore, Egypt may be more likely to heighten the intensity of conflict in order to maintain its dominance in the hydropolitical complex and its control over water-sharing policies. The level of dependence on the shared river is measured as the amount of water extracted from the river as a percent of total water use, which is documented as data by UNESCO and UN-Water.

It is important to reiterate that the measurements of the variables are interval data, which are appropriate for regression analysis. Most of the variables measure change, to indicate the leveraging of types of power rather than the static levels of power, except for geographic power. More information about the indicators, measurements, and data sources can be found in the variable chart in Appendix I. The temporal dynamics of the variables in the CSTS analysis are also informative, as the correlations alone do not demonstrate the direction of causality. For example, an increase in economic leverage, such as market access, may be correlated with an increase in cooperation between riparians in the hydropolitical complex, but the correlation does not determine whether the increase in market access promoted hydropolitical cooperation or the hydropolitical cooperation facilitated an increase in market access. The element of time in the CSTS and the original data must be reviewed to determine whether change in the independent variable precedes change in the dependent variable. Recall, time order is assumed for this analysis because the data are structured in chronological time-series panels with panel-corrected standard errors. This study focuses on factors that contribute to cooperation in hydropolitical complexes and negotiating water-sharing policies, thus, it analyzes the correlations in which changes in the use of political, structural, geographical, ideational, and economic leverage precede changes in the level of conflict or cooperation in international river systems. 


\section{RESULTS}

Table 1. The Effects of Specific Types of Leverage on Cooperation versus Conflict in Hydropolitical Complexes

\begin{tabular}{|c|c|c|c|c|}
\hline \multirow[t]{2}{*}{$\underline{\text { Regressor }}$} & \multicolumn{4}{|c|}{ Type of Leverage Used by Weakest Riparian } \\
\hline & $E Q_{l}$ & Outcome & $E Q_{2}$ & Sustained \\
\hline Geographic & $.81^{*}$ & Conflict & & \\
\hline Military & $.27^{*}$ & Qualified Negotiation & .09 & No \\
\hline Political & .04 & & & \\
\hline Economic & $.11^{*}$ & Negotiation & .01 & Yes \\
\hline Technological & $.08 *$ & Negotiation & .01 & Yes \\
\hline External & $.73^{*}$ & Negotiation & $.28 *$ & Yes \\
\hline Incentive & $.39 *$ & Negotiation & $.07^{*}$ & Yes \\
\hline Constraint & .07 & & & \\
\hline Economic Inequality & $.19^{*}$ & Qualified Negotiation & .09 & No \\
\hline Ethnic Conflict & $.22 *$ & Conflict & & \\
\hline Basin Dependence & $.40^{*}$ & Conflict & & \\
\hline Number & 102 & & 31 & \\
\hline R-square & .57 & & .38 & \\
\hline Regressor & Type & f Leverage Used by Str & arian & \\
\hline & $E Q_{3}$ & Outcome & $E Q_{4}$ & Sustained \\
\hline Geographic & $.68^{*}$ & Conflict & & \\
\hline Military & $.43^{*}$ & Qualified Negotiation & .02 & No \\
\hline Political & $.19^{*}$ & Qualified Negotiation & .01 & No \\
\hline Economic & $.17^{*}$ & Negotiation & .09 & Yes \\
\hline Technological & $.09 *$ & Negotiation & .01 & Yes \\
\hline External & .01 & & & \\
\hline Incentive & $.33^{*}$ & Negotiation & .01 & No \\
\hline Constraint & .09 & & & \\
\hline Economic Inequality & $.08^{*}$ & Qualified Negotiation & .01 & No \\
\hline Ethnic Conflict & $.21 *$ & Conflict & & \\
\hline Basin Dependence & $.23^{*}$ & Conflict & & \\
\hline Number & 102 & & 18 & \\
\hline R-square & .49 & & .21 & \\
\hline
\end{tabular}


HYDROPOLITICAL COMPLEXES AND POWER 228

Table 1 Continued...

Notes:

Central tendency and dispersion for $x<-($ number $=102$, mean $=0$, standard $=1):$ minimum -1.12 , mean 0.17 , maximum 1.41

* Statistically significant at the 0.05 level, two-tailed test.

Equation One: How do the types of leverage used by the weakest riparian affect the outcome of cooperation versus conflict?

$E Q_{1}$ : cooperative, negotiated settlement versus conflict $=b_{1}+b_{2}($ geographic $)+b_{3}$ (military) + $b_{4}($ political $)+b_{5}($ economic $)+b_{6}($ technological $)+b_{7}$ (external $)+b_{8}$ (incentive $)+b_{9}$ (constraint) $+b_{10}$ (inequality) $+b_{11}($ ethnic $)+b_{12}($ dependence $)+e$

Equation Two: If a cooperative, negotiated settlement is achieved, is it sustained?

$E Q_{2}:$ cooperative, negotiated settlement $=b_{1}+b_{2}($ military $)+b_{3}($ economic $)+b_{4}($ technological $)$

$+b_{5}($ external $)+b_{6}$ (incentive $)+b_{7}$ (inequality) at $t_{+1}+e$

Equation Three: How do the types of leverage used by the strongest riparian affect the outcome of cooperation versus conflict?

$E Q_{3}:$ cooperative, negotiated settlement versus conflict $=b_{1}+b_{2}$ (geographic) $+b_{3}$ (military) + $b_{4}($ political $)+b_{5}($ economic $)+b_{6}$ (technological $)+b_{7}($ external $)+b_{8}$ (incentive $)+b_{9}$ (constraint) $+b_{10}$ (inequality $)+b_{11}($ ethnic $)+b_{12}($ dependence $)+e$

Equation Four: If a cooperative, negotiated settlement is achieved, is it sustained?

$E Q_{4}$ : cooperative, negotiated settlement $=b_{1}+b_{2}($ military $)+b_{3}($ political $)+b_{4}($ economic $)+$ $b_{5}($ technological $)+b_{6}$ (incentive) $+b_{7}$ (inequality) at $t_{+1}+e$

Weak riparians in hydropolitical complexes are often coerced to agree to water-sharing policies that adversely affect them. The primary contribution of this research is to provide systematic analysis and statistical evidence to demonstrate that weak riparians can assert economic and soft power in water-sharing negotiations by appealing to and utilizing the capacities of external actors; and that economic and soft power are the most successful in achieving cooperative agreements in hydropolitical complexes. In other words, weak riparians may turn to external third parties such as foreign governments or international financial institutions to assert influence on the strong riparians within the hydropolitical complex, because the external forces have the resources to compensate for the disproportionately low amount of influence of weak riparians. The international community should be knowledgeable about this dynamic because as water scarcity increases and water-sharing policies become more contentious, the role of international actors 
will become more consequential. International influence will be a significant factor in promoting cooperation or provoking conflict in hydropolitical complexes, which affects regional stability and international security.

The results indicate the leverages and strategies used by weak and strong riparians, the outcomes of conflict or negotiated settlements, and the sustainability of the negotiated settlements.

\section{Structural and Hard Power}

Geographic Leverage. In all cases in the study, the country with the geographic advantage asserted it. This is not surprising. If a country controls the headwaters or the upriver point of contention, it uses the geographic advantage as leverage over other countries that may have an advantage in political power, military might, or economic dominance. Ethiopia, for example, is no match for the political, military, and economic prowess of Egypt, but Ethiopia controls the water upriver from Egypt on the Nile. Thus, Ethiopia has at least one powerful bargaining chip, and uses it in times of extreme scarcity; although this test of Egypt's resolve has not been pushed to the point of escalating conflict. The future power plays of Ethiopia and Sudan with Egypt, as well as plausible riparian alliances, is receiving an increasing amount of scholarly attention (Klare 2001) but has yet to produce a source of hard power that trumps the military hard power or economic "sticky" power of Egypt.

The problem verified in this study, however, is that asserting geographic leverage results in conflict in almost all cases. In the case of the Nile, when Ethiopia asserts its geographic advantage, Egypt responds by increasing its political pressure, military threats, and economic leverage, which often exacerbate conflict rather than promote cooperation. In sum, geographic leverage is statistically significant because the riparians that have the geographic advantage use it, but the use of geographic leverage is highly correlated with conflict, not cooperation.

Military Strategy. Countries will mobilize their militaries to protect access to vital water resources. Part of the objective of hydropolitical security complexes is to minimize the need for military mobilization around contentious water issues, and to promote cooperation between interdependent states in international river systems. The results of this research demonstrate that many negotiations over water-sharing policies are qualified negotiated settlements, which indicates that a form of military leverage such as threats or mobilization preceded negotiations. This suggests that the application of military leverage can bring both sides to the negotiation table because military threats, mobilization and use of force are not generally ignored, especially if the military power of the weaker riparian is asserted through terrorist attacks or backed by external military capacity. Other types of leverage such as economic constraints can be neglected while time passes, even if the initial water-sharing dispute is not resolved. The problem with bringing riparians to the negotiating table by threatening or mobilizing military options, is that the subsequent settlements are not sustainable.

\section{Sticky Power}

Economic Leverage. Weak riparians use economic leverage to achieve negotiated settlements on water-sharing policies, and the negotiated settlements are sustainable for at least a year. This can be explained, in part, by the reality that market access is highly coveted. The promise to increase 
market access can serve as an incentive to promote cooperation. Leveraging market access can alter the cost-benefit analysis by making cooperation more beneficial: cooperation will result in gaining access to markets, conflict will be more "costly" because it will result in sanctions or the loss of access to markets. The difference between strong and weak riparians in this regard, is that the strong riparians can assert economic leverage based on their own markets and assets, while weak riparians often have to turn to external actors such as the World Bank to provide economic incentives and constraints on their behalf to promote cooperation in the region.

\section{External Influence}

To avoid being coerced to accept water-sharing policies that adversely affect them, weak riparians often appeal to external forces to assert power and leverage in the negotiations of hydropolitical security complexes. The use of external influence is statistically significant in promoting cooperation in hydropolitical complexes, and the negotiated settlements are sustainable. As concluded by Arun Elhance, international financial institutions can offer "powerful economic leverages to persuade reluctant states to cooperate," and the cooperative arrangements tend to endure at least as long as the aid keeps flowing (2000:216). The promise of international aid can serve as an incentive to resolve resource disputes through cooperation. Donor organizations can design aid programs to alter the cost-benefit analysis of resolving disputes through negotiated settlements as opposed to violent conflict. Recipient countries can use international financial aid to promote development, build infrastructure, increase government capacity to provide public services, and many other projects to increase economic and political stability. Financial aid operates through mechanisms such as contingencies on how the money can be used and what degree of accountability must be achieved. In addition to general development goals, "aid conditionality can help strengthen incentives for ending conflict and discourage a return to war" (Boyce 2002). For example, the World Bank will give financial aid to help develop large regional water supply systems for potable water, irrigation, and hydroelectric projects. However, the loans are contingent on the agreement and cooperation of all riparians. If one riparian does not agree with the proposed water development project, the World Bank will withhold financial aid until a negotiated settlement can be reached.

\section{Soft, Political, and Ideational Power}

Political Leverage. Political leverage is not a statistically significant factor in the capacity of weak riparians to promote cooperation, but it does correlate with the ability of strong riparians to achieve negotiated settlements. This is interesting for two main reasons. First, political legitimacy is significant for strong riparians but not for weak riparians, presumably because strong riparians meet a threshold of legitimacy that allows them to offer credible political gains and to allocate political losses, whereas weak riparians do not generally have the capacity to do so. Second, it exposes a probable source of multicollinearity, which was tested and verified, between military power, political legitimacy, and economic resources. Political leverage is only effective in cases where the riparian has overlapping advantages in military capacity and economic assets that can be leveraged. In addition, the settlements are qualified negotiated settlements, which means that the negotiations were preceded by military actions such as threats or mobilization, and the settlements are not sustainable. The weaker riparian may have 


\section{JOURNAL OF WORLD-SYSTEMS RESEARCH}

succumbed to political pressure to conform to policies that adversely affect them, but these policies may not be sustainable if the political pressure lets up for any reason in the future.

Diffusion of Technology. The capacity to leverage access to valuable technologies can bring riparians to the negotiating table. Both strong and weak riparians can offer to provide or use technologies that increase water-use efficiency or produce hydroelectric power, which may have distinct benefits or consequences for different riparians. The primary issue with leveraging technology, however, is that most countries will turn to external sources to gain access to new technologies or the money to finance them. International financial institutions such as the World Bank typically get involved in large infrastructure development projects and technology transfers. The definitive work of Bertram Spector demonstrates that cooperation often depends on external "facilitating elements" such as technology, which can be engineered to promote cooperation and prevent conflict (Spector 2000: 224).

Contextual Factors. There is a complicated relationship between economic inequality and regional conflict. Economic inequality can provoke violent conflict within and between countries. Regarding resource disputes, however, economic tensions have a dual effect: inequality can exacerbate conflict or bring countries to the bargaining table. The statistical results of this study show that economic inequality results in qualified negotiated settlements; negotiations that follow volatile disputes, which indicates that contradictory forces are in play. In contrast, the effects of ethnic conflict are clear and consequential. Ethnic conflict disrupts the negotiation process and distracts the attentions and resources of the participants. It is not surprising that ethnic conflict has a statistically significant correlation with the continuation of conflict. Another complicating factor is the level of dependence on the shared river system. A high level of dependence means a high likelihood of conflict. However, the implications of this

finding are more substantial. As demand increases and water scarcity increases, the level of competition to control the resource will also increase. Strategies for conflict prevention and resolution will need to address this increase in the intensity of competition to control the water source.

\section{CONCLUSION}

Weak riparians are most successful at influencing water-sharing policies when they utilize the resources of external actors to augment their economic and technological capacity. With external support, weak riparians can assert economic leverage and soft power, which this study shows to be the most effective in achieving cooperation in hydropolitical complexes. However, these exogenous sources of influence are used the least often. The types of power that are asserted most frequently are geographic location and military capacity, which are shown in this study to be the least successful in achieving consistent cooperation and sustainable settlements. The general conclusion is highly problematic for the cooperative management of international river systems: the strategies that are the most successful at promoting cooperation are used the least often. This is, in part, because hydropolitical complexes are intended to be regional security organizations that promote regional stability and prosperity concerning shared water resources. However, if weak riparians find that they are being coerced to accept water-sharing policies that adversely affect them, owing to power asymmetry in the regional complex, they may turn to external actors to gain the leverage necessary to negotiate better arrangements. A positive spin on this finding is 
that the external actors tend to augment economic and soft power, as opposed to promoting hard power. There are known strategies for asserting economic power, such as altering the amount of trade and aid, and for leveraging soft power, such as technology transfers, that can be used to increase cooperation. This serves the objectives of hydropolitical complexes, albeit indirectly, to increase regional cooperation and achieve negotiated settlements for water-sharing policies in shared river systems.

The weakest riparians do not have the economic resources, political capacity, or nonviolent leverage to balance asymmetrical power in hydropolitical complexes, so they often appeal to external actors to augment their power. The cross sectional analysis provides empirical evidence to support the importance of external international influence on asymmetrical power relations and cooperation within hydropolitical complexes. The role of external actors will become increasingly important in the internal power dynamics of hydropolitical complexes as competition between riparians intensifies. The decision to promote cooperation or provoke conflict will become more consequential as water use and water scarcity increase. International actors that choose to get involved in international water disputes and regional hydropolitical complexes will need to keep pace with these changes.

Future research needs to disaggregate the findings of this study, and others, as well as analyze the motives behind international involvement in hydropolitical complexes. We cannot ignore the temptation of external actors to manipulate water disputes in order to increase or maintain their own access to vital resources. New research also needs to be conducted on the effects of multinational corporations, as external international actors, asserting leverage in hydropolitical complexes. A systematic comparative analysis of variation in the strategies and outcomes of foreign influence by multinational corporations, foreign governments, and international financial institutions would be informative. As water becomes increasingly privatized and corporations consolidate their control over vital resources, it is useful to anticipate the impact on international river systems so that the international community can offer alternative forms of economic and soft power to promote cooperation and prevent conflict.

\section{ACKNOWLEDGEMENTS}

The author appreciates the generous financial support from the Research Council and Office of Research and Sponsored Programs at Rutgers University, as well as the constructive comments from a team of colleagues and anonymous reviewers.

\section{REFERENCES}

Boyce, James. 2002. Investing in Peace: Aid and Conditionality after Civil Wars. Adelphi Paper 351. Oxford: Oxford University Press for the International Institute for Strategic Studies.

Braudel, Fernand. 1979. Civilisation matérielle, économie et capitalisme, XVt-XVIII siècle, le temps du monde vol. 3. Paris: LGF Publishers (1979) and Berkeley: University of California Press (English translation 1992).

Browder, Greg. 2000. "An Analysis of the Negotiations for the 1995 Mekong Agreement." International Negotiation 5: 237-261. 


\section{JOURNAL OF WORLD-SYSTEMS RESEARCH}

Chase-Dunn, Christopher and Peter Grimes. 1995. "World-Systems Analysis." Annual Review of Sociology 21: 387-417.

Dinar, Ariel and Senai Alemu. 2000. "The Process of Negotiation Over International Water Disputes: The Case of the Nile Basin." International Negotiation 5: 331-356.

Dinar, Shlomi. 2000. "Negotiations and International Relations: A Framework for Hydropolitics." International Negotiation 5: 375-407.

Elhance, Arun P. 2000. "Hydropolitics: Grounds for Despair, Reasons for Hope." International Negotiation 5: 201-222.

Elhance, Arun P. 1999. Hydropolitics in the Third World: Conflict and Cooperation in International River Basins. Washington D.C.: United States Institute of Peace Press.

Klare, Michael. 2001. Resource Wars: The New Landscape of Global Conflict. New York: Henry Holt and Company.

Le Billon, Philippe. 2005. Fueling War: Natural resources and armed conflict. New York: The International Institute for Strategic Studies.

Lukes, Steven. 1997. Power: A Radical View. Palgrave Macmillan.

Mead, Walter Russell. 2004. "America's Sticky Power." Foreign Policy 141: 46-53.

NATO. 1999. See levels of conflict: durable peace, stable peace, unstable peace, crisis, war, with variations developed by NATO 1998, ratified and institutionalized in 1999.

Nye, Joseph. 2004. Soft Power: The Means to Success in World Politics. New York: Perseus.

Posthumus, Bram. 2000. "Nile Basin Nations Move Towards Cooperation." European Platform for Conflict Prevention and Transformation. Conflict Prevention Newsletter Special on Water and Conflict, One World 3: 4-7, 13-20.

Spector, Bertram. 2000. "Motivating Water Diplomacy: Finding the Situational Incentives to Negotiate."International Negotiation 5: 223-236.

Wallerstein, Immanuel. 1974. The Modern World-System, vol. I: Capitalist Agriculture and the Origins of the European World-Economy in the Sixteenth Century. New York and London: Academic Press.

Zeitoun, Mark and Jeroen Warner. 2006. "Hydro-hegemony." Water Policy 8: 435-460. 


\section{APPENDIX}

\section{A. International River System Specification}

Amazon Basin

Bolivia, Brazil, Colombia, Ecuador, French Guyana, Guyana, Peru, Suriname, Venezuela

Ganges and Brahmaputra Basin

Bangladesh, Bhutan, China, India, Myanmar, Nepal, Tibetan disputed territory

Indus Basin

China, India, Kashmiri disputed territory, Pakistan

Jordan Basin

Israel, Jordan, Lebanon, Palestinian disputed territory, Syria

Nile Basin

Burundi, Congo-Zaire, Egypt, Ethiopia, Kenya, Rwanda, Sudan, Tanzania, Uganda

Parana and La Plata Basin

Argentina, Bolivia, Brazil, Paraguay, Uruguay

Tigris and Euphrates Basin

Iran, Iraq, Syria, Turkey

Zambezi Basin

Angola, Botswana, Congo-Kinshasa, Malawi, Mozambique, Namibia, Tanzania, Zambia, Zimbabwe 


\section{B. Variable Specification}

\begin{tabular}{|c|c|c|c|c|}
\hline Category & Indicator & Variable & Measure & Data Source \\
\hline Hard Power & Military & $\begin{array}{l}\text { Level of military } \\
\text { mobilization }\end{array}$ & $\begin{array}{l}\text { Change in troop levels on } \\
\text { the border of riparian } \\
\text { states }\end{array}$ & Correlates of War \\
\hline Hard Power & Geographic & $\begin{array}{l}\text { Control of } \\
\text { headwaters }\end{array}$ & Proximity to headwaters & $\begin{array}{l}\text { UNESCO: UN- } \\
\text { Water }\end{array}$ \\
\hline $\begin{array}{l}\text { Sticky } \\
\text { Power }\end{array}$ & Economic & $\begin{array}{l}\text { Total trade plus aid } \\
\text { from a riparian state }\end{array}$ & $\begin{array}{l}\text { Total trade plus aid from } \\
\text { riparian state, as percent of } \\
\text { GDP }\end{array}$ & $\begin{array}{l}\text { World Bank, } \\
\text { Bilateral Trade and } \\
\text { Aid } \\
\end{array}$ \\
\hline Soft Power & Political & $\begin{array}{l}\text { Political } \\
\text { accountability }\end{array}$ & $\begin{array}{l}\text { Change in level of } \\
\text { democratic accountability }\end{array}$ & $\begin{array}{l}\text { Governance } \\
\text { Indicators, World } \\
\text { Bank }\end{array}$ \\
\hline Soft Power & $\begin{array}{l}\text { Ideational } \\
\text { diffusion }\end{array}$ & Technology transfer & $\begin{array}{l}\text { Change in amount of } \\
\text { technological capacity }\end{array}$ & World Bank \\
\hline $\begin{array}{l}\text { External } \\
\text { Power }\end{array}$ & $\begin{array}{l}\text { Involvement of } \\
\text { a third party }\end{array}$ & $\begin{array}{l}\text { Total trade plus aid } \\
\text { from an external } \\
\text { actor }\end{array}$ & $\begin{array}{l}\text { Change in the level of total } \\
\text { trade plus aid from } \\
\text { external source }\end{array}$ & World Bank \\
\hline Incentive & $\begin{array}{l}\text { Perceived } \\
\text { positive } \\
\text { character of } \\
\text { leverage }\end{array}$ & Incentive & $\begin{array}{l}\text { Dummy variable, } 1= \\
\text { incentive, } 0=\text { no incentive }\end{array}$ & $\begin{array}{l}\text { Inter-coder } \\
\text { reliability over } 98 \%\end{array}$ \\
\hline Constraint & $\begin{array}{l}\text { Perceived } \\
\text { negative } \\
\text { character of } \\
\text { leverage } \\
\end{array}$ & Constraint & $\begin{array}{l}\text { Dummy variable, } 1= \\
\text { constraint, } 0=\text { no } \\
\text { constraint }\end{array}$ & $\begin{array}{l}\text { Inter-coder } \\
\text { reliability over } 98 \%\end{array}$ \\
\hline Contextual & $\begin{array}{l}\text { Economic } \\
\text { inequality }\end{array}$ & $\begin{array}{l}\text { Economic inequality } \\
\text { between riparians }\end{array}$ & $\begin{array}{l}\text { Economic disparity in } \\
\text { GDP pc between riparians }\end{array}$ & UNDP \\
\hline Contextual & Ethnic conflict & Ethnic conflict & $\begin{array}{l}\text { Change in the number of } \\
\text { ethnic events reporting } \\
\text { human injuries }\end{array}$ & Correlates of War \\
\hline Contextual & $\begin{array}{l}\text { Dependence on } \\
\text { shared river }\end{array}$ & $\begin{array}{l}\text { Dependence on } \\
\text { shared river }\end{array}$ & $\begin{array}{l}\text { River water extraction as } \\
\text { percent of total water use }\end{array}$ & $\begin{array}{l}\text { UNESCO: UN- } \\
\text { Water }\end{array}$ \\
\hline
\end{tabular}

